\title{
Bone Marrow Mononuclear Cell
}

National Cancer Institute

\section{Source}

National Cancer Institute. Bone Marrow Mononuclear Cell. NCI Thesaurus. Code C156591.

Any cell with a single nucleus found in the bone marrow, for example lymphocytes, monocytes, mesenchymal stem cells and hematopoietic progenitor cells. 